\title{
Markov Stability partitioning shows spectrally dependent community structure amongst thalamocortical neural ensembles
}

\author{
Christian-David Martin*, Silvia Ardila-Jimenez, Simon Schultz
}

From 24th Annual Computational Neuroscience Meeting: CNS*2015

Prague, Czech Republic. 18-23 July 2015

The processing of information through the spatiotemporal coordination of neuronal activity is still poorly understood [1]. Here we analyse local field potential (LFP) signals from multi-electrode recordings in the mouse lateral geniculate nucleus (LGN) and visual cortex (V1), to systematically investigate interactions between neuronal ensembles across the frequency spectrum. Computing mutual information for each pair of electro- des using the k-nearest neighbor method developed by [2], two broad groupings can be discerned among the electrodes (Figure 1A). The same partitioning is found as a stable solution when applying the Markov Stability algorithm developed by Billeh et. al. [3], which uses a Markov diffusion process through the dataset to detect stable groupings (Figure 1B/C). Analysing narrowband filtered LFP signals, neuronal groupings were found to

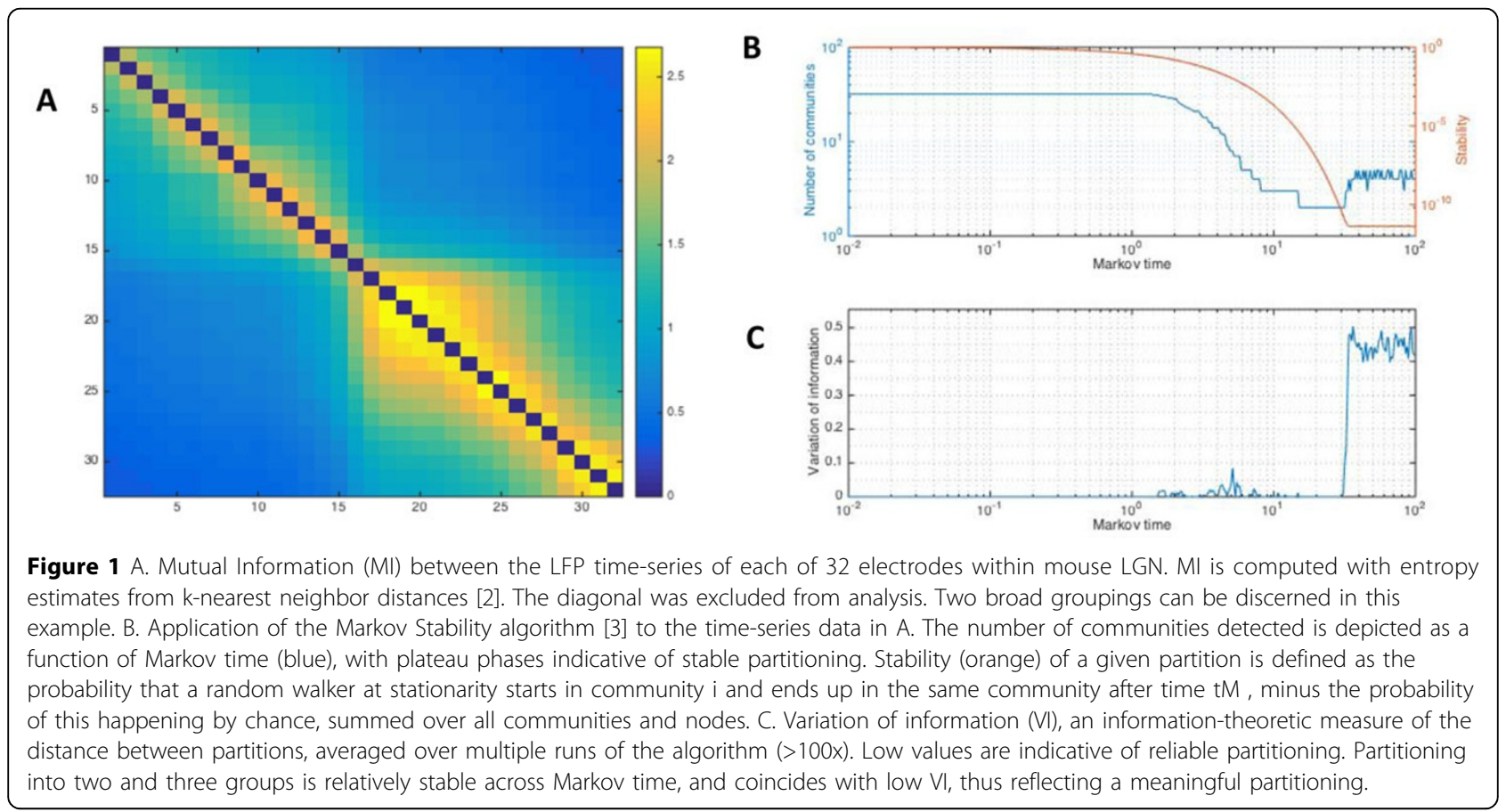

\footnotetext{
* Correspondence: c.martin14@imperial.ac.uk

Centre for Neurotechnology \& Department of Bioengineering, Imperial College London, London, UK
} 
change between low $(1-40 \mathrm{~Hz})$ and high $(>40 \mathrm{~Hz})$ frequency bands. One particular neural ensemble was found to participate in different groupings across low and high frequency bands, with differing interaction partners and mechanisms as assessed by phase-phase and phaseamplitude correlation measures, both within and across areas. This frequency-specific interaction pattern may allow for the simultaneous coordination of information transmission across different timescales.

Published: 18 December 2015

\section{References}

1. Aru J, Aru J, Priesemann V, Wibral M, Lana L, Pipa G, Singer W, Vicente R: Untangling cross-frequency coupling in neuroscience. Current Opinion in Neurobiology 2015, 31:51-61.

2. Kraskov A, Stoegbauer $H$, Grassberger P: Estimating Mutual Information. Phys Rev E 2004, 69(6):1-16.

3. Billeh YN, Schaub MT, Anastassiou CA, Barahona M, Koch C: Revealing cell assemblies at multiple levels of granularity. Journal of Neuroscience Methods 2014, 236:92-106.

doi:10.1186/1471-2202-16-S1-P222

Cite this article as: Martin et al:: Markov Stability partitioning shows spectrally dependent community structure amongst thalamocortical neural ensembles. BMC Neuroscience 2015 16(Suppl 1):P222.

Submit your next manuscript to BioMed Central and take full advantage of:

- Convenient online submission

- Thorough peer review

- No space constraints or color figure charges

- Immediate publication on acceptance

- Inclusion in PubMed, CAS, Scopus and Google Scholar

- Research which is freely available for redistribution

Submit your manuscript at www.biomedcentral.com/submit 